\title{
CORRECTION
}

\section{Correction to: Phosphorus Use Efficiency in Permanent Pastures in Andisols}

\author{
Erika Vistoso $^{1} \cdot$ Sergio Iraira ${ }^{1} \cdot$ Patricio Sandaña ${ }^{2}$
}

Published online: 3 September 2021

๑) Sociedad Chilena de la Ciencia del Suelo 2021

\section{Correction to: Journal of Soil Science and Plant Nutrition} https://doi.org/10.1007/s42729-021-00526-9

Equation 5 and Fig. 2 as they appeared in this article as originally published stood in need of correction.
The correct Eq. 5 and Fig. 2 are provided below. The original article has been updated.

$\mathrm{P}$ available $=\left(\left(\right.\right.$ Olsen $\left.-\mathrm{P}\left(\mathrm{mg} \mathrm{kg}^{-1}\right)\right) *(10000 \times$ depth $\times \mathrm{BD})+\mathrm{P}$ application rate
$\left(\mathrm{kg} \mathrm{Pha}^{-1}\right)$
$\left(\left(0.14\left(\mathrm{mg} \mathrm{kg}^{-1}\right)\right)\right.$
(1000000)
$\left(\mathrm{kg} \mathrm{Pha}^{-1}\right)$

The original article can be found online at https://doi.org/10.1007/ s42729-021-00526-9.

Erika Vistoso

evistoso@inia.cl

1 Instituto de Investigaciones Agropecuarias, INIA Remehue, Ruta 5 Sur km 8 Norte, Osorno, Chile

2 Institute of Plant Production and Protection, Universidad Austral de Chile, Campus Isla Teja, Valdivia, Chile 


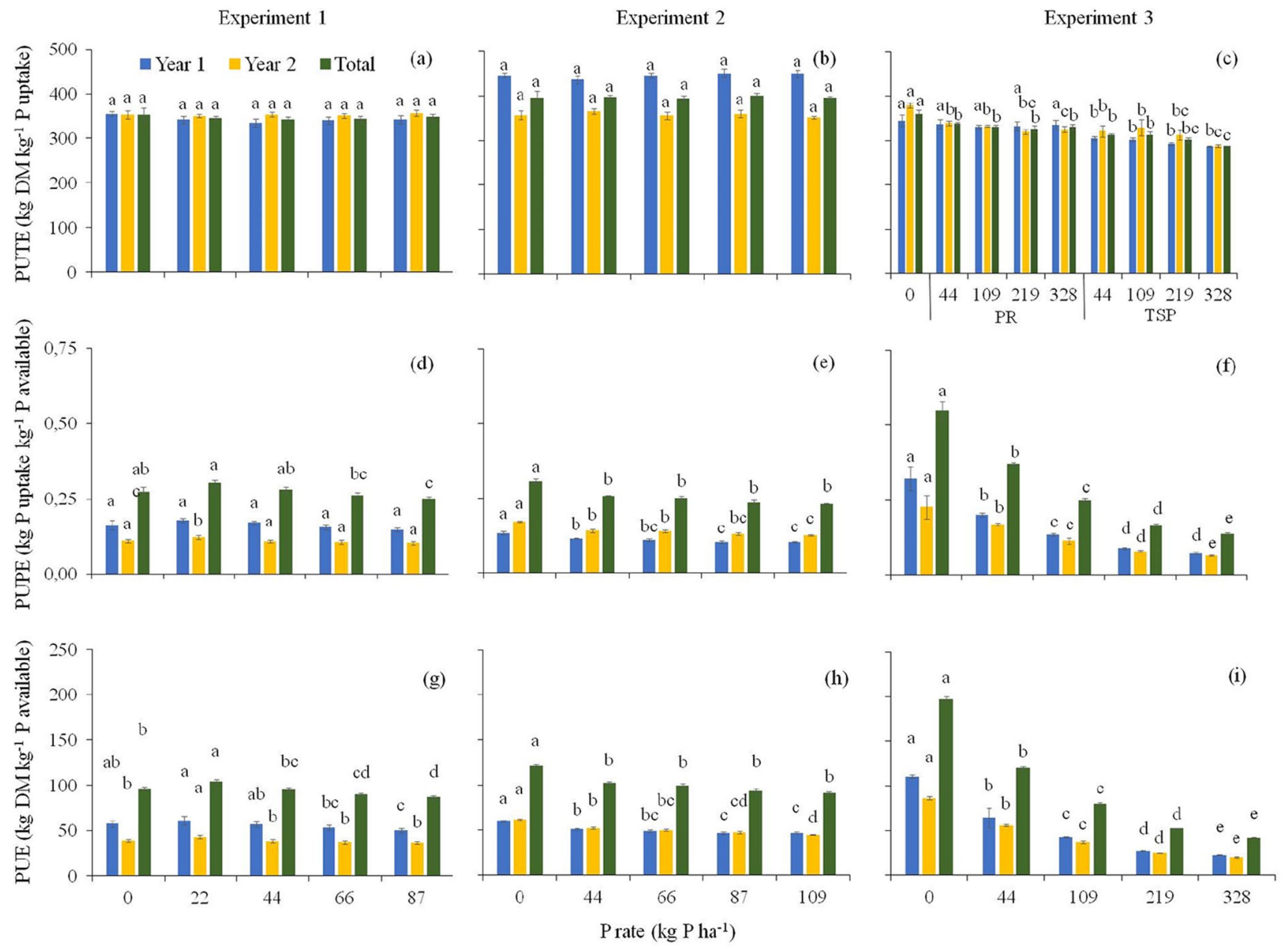

Fig. 2 Cumulative P utilization efficiency (PUTE) (a, b, c), P uptake efficiency (PUPE) $(\mathbf{d}, \mathbf{e}, \mathbf{f})$ and $\mathrm{P}$ use efficiency (PUE) $(\mathbf{g}, \mathbf{h}, \mathbf{i})$ in year 1,2 and total in experiments 1 (left panels), 2 (middle panels) and 3 (right panels). With the exception of PUTE in c, PUTE, PUPE and PUE were averaged across $\mathrm{P}$ sources (phosphate rock (PR) and tri- ple superphosphate (TSP)) according to ANOVA results (Table 1). In c, PUTE was disaggregated according to the significant Source $\mathrm{x} P$ rate interaction from ANOVA. Period: September 2013-October 2014 ( \pm standard error, $n=3$ ). Different letters indicate differences between $P$ rates (within each year) obtained with the Fischer $T$ test ( $\mathrm{p}$ 0.05)

Publisher's Note Springer Nature remains neutral with regard to jurisdictional claims in published maps and institutional affiliations. 